\title{
ASEAN Centrality in Asian Regional Architecture
}

\author{
Frassminggi Kamasa \\ Direktorat Jenderal Amerika dan Eropa, Kementerian Luar Negeri
}

\begin{abstract}
This study examines the regional architecture process in Asia. Specifically, I empirically focus on what ASEAN's role in contemporary Asian regional architecture is and what challenge and opportunities lie ahead. In contrast to other studies, I consider whether the ASEAN as a driving force of the regional architecture in Asia should only be considered in an over-arching macro-analytical sense in order to contain China. Such an approach to the concept may not work in explaining what change in Asia and its relations with the ASEAN centrality. Additionally, I consider why there is a need for regional architecture in Asia. Using a single-case analysis of ASEAN role in regional architecture from 2009-2012, I found evidence of an association between bargaining and mutual satisfaction while embracing different motives and power for doing regional architecture. Moreover, I demonstrate that it makes sense to talk about regional identity whenever ASEAN is struggling to project a common voice.
\end{abstract}

Keywords: ASEAN, ASEAN Centrality, Asia, regional architecture, strategic.

\begin{abstract}
Abstrak
Studi ini akan meneliti proses arsitektur regional di Asia. Secara spesifik dan secara empiris, penulis akan fokus pada pertanyaan "apa peran ASEAN dalam arsitektur regional Asia kontemporer?" dan "apa tantangan dan peluang yang ada?'. Berbeda dengan studi lainnya, penulis akan menilai ASEAN sebagai kekuatan pendorong arsitektur regional di Asia hanya dianggap untuk membendung pengaruh Cina di kawasan atau tidak apabila dilihat dari analisis makro. Pendekatan konsep semacam itu mungkin tidak bekerja dalam menjelaskan perubahan yang terjadi di Asia dalam hubungannya dengan sentralitas ASEAN. Sebagai tambahan, penulis akan memperhatikan alasan adanya kebutuhan untuk terciptanya arsitektur regional di Asia. Dengan menggunakan analisis studi kasus tunggal mengenai peran ASEAN dalam arsitektur regional tahun 2009-2012, penulis menemukan bukti adanya hubungan antara tawar menawar dan keuntungan bersama sembari merangkul berbagai motif dan kekuatan yang berbeda untuk membina arsitektur regional. Selain itu, penulis akan menunjukkan bahwa adalah hal yang masuk akal untuk membahas identitas regional setiap kali ASEAN sedang berusaha untuk memproyeksikan suara bersama di fora internasional.
\end{abstract}

Kata kunci: ASEAN, Sentralitas ASEAN, Asia, arsitektur regional, strategis. 


\section{Introduction}

Many experts believe that the $21^{\text {st }}$ century will be the Asia Age. It is perhaps here, in the Asia, where the outline of a new world order is taking shape today, and a new image of the global management system is emerging. That global management system is underway in Asia in the form of the Regional Architecture (RA) based on the principles of equality, transparency, polycentricity, supremacy of law, respect of sovereignty, and mutual consideration of the interests of all states in the region.

The RA in Asia has emerged since the signing of the Treaty of Amity and Cooperation (TAC) in Southeast Asia. This study investigates the RA in Asia from 2009-2012. When I speak of 'Asia', what I mean is a region where the process of RA between Southeast Asia (SEA) and East Asia (EA) is unfolding.

My research question is: "What is ASEAN's role in contemporary Asian RA and what challenge and opportunities lie ahead?" The study's hypotheses may include the following: (1) Asia's future is linked to the future of the world and the future of the world depends on the Asia that will lead to RA, (2) The need to offset, complement, and elaborate upon American dominance and China's rising influence in Asia will lead to RA.

My first thesis is that a new image of global management system is emerging in Asia with the region itself is also undergoing major metamorphoses. These include, above all, an unprecedented growth of interdependence and interconnection between the countries of the region and an acceleration of multi-level economic integration. My second thesis is that in the complex multidimensional process of interdependence and interconnection, the state's capacity for independent political action is weakened. These ideas will elaborate more and explore with relevant literature.

According to Barry Buzan and Ole Waever (Buzan \& Waever, 2003: 45-6o), RA is an important tool to craft amity or enmity in the security and economic interdependence. This is because the presence of several global powers in the international systems raises questions about how great powers and superpower interact with regions. I agree with this idea because the Asian countries are increasingly aware that peace and stability in the region can only be ensured by combining their efforts and taking measures to consolidate security on a collective and nonbloc basis.

According to Michael Wesley (2009: 49-65), the US has created institutions after the Second World War as a way of assuring lesser powers in the region was constrained by a series of institutional commitments and enabled it to play a more directly hegemonic role in the protection of regional order. I agree with this idea because a web of organizationspublic and private, domestic and international-that shapes political regimes and policy, sets standards, and enforces rules on a wide range of issues decided by the US has made states lack effective authority.

I will divide this study into three sections. The first section examines how regional identity has been evolving in the new strategic environment in Asia. The second section analyzes how RA proceeds in Asia with the ASEAN centrality. The third section investigates what challenges and opportunities lie ahead.

\section{Literature Review}

The discourse on RA in Asia and ASEAN role on it is not extensive. There are three debates evolving RA in Asia. The first is focused on several clusters of assumptions on what RA is exactly. Second, who actually belongs to, or should belong to, such an entity. And third, what purposes it is intended to serve (East Asia Vision Group Report, 2001; East Asia Vision Group, 2002; Bisley, 2007; Tow \& Taylor, 2010; Clinton, 2010;). Since its founding more than 40 years ago, the ASEAN has expanded from an original five member state organization to its current size of 10 members. It now has a Charter, which will serve as its guiding framework in its continuing progression toward the future. Recent study of what ASEAN's role is in contemporary Asian RA and what challenges and opportunities that will lie ahead tells us that it is to "provide transparency and overlapping venues in which to discuss a range of issues and disagreements." (Dormandy, 2012: 18). The 'ASEAN way' as a neutral set of rules for regional cooperation in Asia has worked 
constructively in balancing RA process to produce independent order that correlates with global stability (Tow, 2009; Acharya, 2007; Nishikawa, 2007).

Right now, ASEAN is trying to map out the prospects for its further development and is discussing the ways of building a better security and cooperation architecture in the Asia-Pacific region. Many scholars have pointed out that the shift of global politics and economic gravity to Asia-Pacific makes the architecture building in the region more complex in a coherent and cohesive stance (Friedrichs, 2012; Nanto, 2008; Rachmianto, 2011; Bisley, 2007; Goh, 2005; Reyes et al, 2004). There is continuity of historical enmity between China, Japan, and Korea (CJK) and battle of sphere of influence between the US and China to create order in the region. This has made ASEAN seek to contribute to prosperity and security in the region by engaging the major powers in regular consultations and through networks of relationship and Confidence Building Measures (CBM) revolving around the association (Wesley, 2009; Severino, 2006; Chalmers, 1997; Acharya, 1993). Therefore, ASEAN as the most developed and durable organization in the Asia-Pacific has exerted its importance, independence, and proactive approach to construct multilayered architecture(s) that is open and transparent for all ideas, visions, and adjustments (Kemlu RI, 2010; Buzan, 2003). Thus, in Contemporary Southeast Asia: Regional Dynamics and National Differences, Marc Besson (Besson,

${ }^{1}$ The term of post-nationalism refers to the critique of the concept of the nation as the central organizing principle of modern political identity and government. Postnationalism related with the concept of world government that refers to the institutional organization and administration of global affairs, including issues of peace and security, economics, the environment, and the potential constitution of a comprehensive international system of law and justice. I might be wrong, but, the tendency of RA for me seems like a federation or federal states that are controlled by centralized authority. In
2004: 215) points out “ASEAN's important role in promoting the development of regionallybased, exclusively Asian mechanism with which to manage intra-regional relations is a potentially important indicator of future trends." In each of these analyses, it is imperative for ASEAN to remain harmonious and solid to project common and refined voices in spite of different interest and power in order to construct RA in Asia.

\section{Strategic Environment and Regional Identity in Asia}

'Strategic' according to the MerriamWebster's dictionary (2012) is the "relating to strategy of great importance to a planned effect designed to strike an enemy at the sources of its military, economic, or political power." Organizations are affected by every facet of their external environment. Therefore, strategic environment could be defined as strategic planning process to assess, respond, and adjust the changing environment for organization's direction (National Defense University, 2012; Encyclopedia of Management, 2009; Kapuchu, 2007; Xu, 2007; Ireland \& Hitt, 2005). Strategic environment is in relation with regional identity in Asia as a recognized way of anticipating post nationalism in form of a 'culture as destiny' (Darity Jr, 2008; Ball, 1999). ${ }^{1}$ This was spread in the mid-1990s as "several Asian leaders and thinkers sought to resist the spread of liberal 'market civilization' by appealing to the cultural specificity of Asian values" (Hall \& Jackson, 2007: 187).²

Desmond Ball's book, he proposed three structures that connected twenty five regional actors in a group of nexus of an unequal types and strengths. It is likely that Asia is getting aware of this tendency and tries to fix the loopholes on it to become more equal, legitimate and transparent.

${ }^{2}$ It is also related with identity theory that recognizes the possibility of choice as a ubiquitous feature of human existence. At the same time, however, identity theory recognizes the sociological truth that social structure and social interaction are equally ubiquitous in constrainingnot in a strict sense "determining"-human action 
Over the past decade, the process of regional integration, the impact of global crisis, and political and security cooperation in Asia have created an RA which serves as an avenue of cooperation and dialogue among countries in the region. RA can be defined as reasonably coherence network of regional organizations, bilateral institutions, multilateral arranged dialogue forum and other relevant mechanism that work collectively for regional prosperity, peace, and stability (Racmianto, 2011; Tow \& Taylor, 2010). 3

In my view, Asia is one of the world's most strategic environments with strategic characteristics in its physical environment, national character, nexus of power structure, and balance of power mechanism. Despite its volatile and sensitive region, there are several flash points and the meeting of economic interests in Asia. The region is vitally important to the US'and China's economic and security interests (Clinton, 2010; Jiechi, 2007). The region has the world's heaviest concentration of military and economic capabilities.

Three largest economies on a purchasing power parity basis reside here; namely, China, Japan, and ASEAN. CJK is the world's largest trading countries in 2010 after EU-27 and the US. There is also Hong Kong, Singapore, and Russia in the top ten positions (European Union, 2011). China, Japan, and Russia respectively sit on the second, third, and ninth places in terms of world's largest economies (Bergmann, 2011; the Economist, 2010). I consider Russia as part of Asia because they are geographically located in Asia and their ethnics and histories are not that separated from the rest of Asia.

This region is home to the world's largest holders of foreign exchange reserves in 2011; namely China followed by Japan, Russia, Taiwan, and South Korea respectively in the second, third, fifth, and seventh place (Morrison \& Labonte, 2011; World Bank, 2011; Donghyun \& Estrada, 2009) Japan remains the world's second-largest financial contributor to

(Stryker, 2001).

3 I think strategic environment is also a factor influencing capabilities for strategic choices for regional identities to the UN and its associated specialized agencies. The rising China as the world's fastest economic growth in the post-Cold War era will become the world's largest trading country in 2016 according to the latest HSBC global trade report published in February 2012 (Leung, 2012).

The EA is inextricably linked with ASEAN in form of geographical proximity, culture, and historical relationship. ASEAN is a strategic backyard for the EA nations and vice versa. ASEAN provides stability in the region and is gradually reshaping the global balance of power. The region is an arena of considerable strategic geopolitical and geo-economics. To be specific about ASEAN, it covers an area of 4.46 million square kilometers, with a population of approximately 598 million people (about $8.8 \%$ of the world population). In 2011, its combined nominal GDP had grown to $\$ 1.8$ trillion, despite significant disparities still prevailing across the region (the ASEAN Secretariat, 2012: 1-4). Today, according to Nehru (Nehru, 2011), SEA is characterized by high economic growth in most countries and closer regional integration. SEA's ten countries have a combined GDP of $\$ 1.8$ trillion (bigger than India), a population of almost 600 million people (nearly twice that of the US), and an average per-capita income $\$ 3.0925$ (near that of China). Over the last decade, the countries have averaged a growth rate of more than 5 percent per year (Budiman, 2008). If SEA were one country, it would be the world's ninth largest economy. It would also be the most trade-dependent, with a trade-to-GDP ratio in excess of 150 percent, and one of the world's consistently good performers (Rasyid, 2008).

Security developments in Asia are intrinsically important to an understanding of global security. Both China and Russia are nuclear weapons states. North Korea is a seminuclear state. Three states are on the threshold of obtaining nuclear weapon; namely, Japan, South Korea, and Taiwan (World Nuclear Association, 2013).

The divide in Asia between regional

construct RA because they are constrained by their environments. 
and global politics substantially overlaps. The region is the strategic home for two of the five permanent members of the UNSC. Asia, in the post of the Second World War, provides a striking illustration of the enormous impact that external intervention can have on local battle death toll (Human Security Report Project, 2011). The post-Cold War order has had a significant impact on the region's strategic and security concerns. Asia provides a compelling illustration of the thesis that economic development is a critically important form of long-term conflict prevention (Human Security Report Project, 2011).

The rising influence of Asia represents a remarkable and historic global shift. This remarkable change and dynamism clearly can be seen in the rise of China as a new regional power, the relative decline of Japan as an old regional power, and the US strategic pivot towards Asia. In the middle of it there is ASEAN as a middle power that constitutes low and middle powers in the region. Furthermore, Russia still keeps an eye on region (Medvedev, 2010). It is interesting to see the reengagement of US vis-à-vis rising China in the region in connection with ASEAN's central role.

\section{ASEAN Centrality}

ASEAN centrality is the stabilizer to keep the dynamics and to advance security and prosperity in the region. I think the survival of the architecture building in Asia depends on the ASEAN centrality. ASEAN's role is central to this process. The readiness of ASEAN to lead it, and whether the US and China are willing to acknowledge ASEAN's lead, depends on ASEAN solidity to project their vision after the robust development of the association as it stands. I think there are, at least, three salient forms of ASEAN centrality in today's Asian RA which are as a norms creator, as a producing order, and as an association that reconciles the economic-security nexus.

First, as a norms creator, ASEAN opens new possibilities and offering alternatives of the process of RA offered by the US and China. Norms are molded by regimes, according to Stephen Krasner, and it related with social constructivism, according to John Ruggie. According to Krasner (1982: 2), "regimes can be defined as sets of implicit principles, norms, rules, and decision-making procedures around which actors expectations converge in a given area of International Relations (IR).” According to Ruggie (2003: 97), "norms can be thought in limited instances as 'causing' occurrences. Norms may guide behavior, they may 'inspire' behavior, they may 'rationalize' or 'justify' behavior, and they may express 'mutual expectations' about behavior." Therefore, ASEAN as an institution is setting the regimes that facilitate win-win cooperation.

From a macro-analysis, I think ASEAN puts a high value on the process of RA in a broad, loose, informal, and multilayered way that is open for any regional interests to achieve prosperity and stability. ASEAN norms are known as the ASEAN way and the final outcomes of bargaining in ASEAN.

I think norms do not necessarily need to exist in a formal sense in order to be valid. What-most important is to strengthen domestic capability of each member, and to foster sharing and a caring spirit. I acknowledge that there is ASEAN Community with a 'legal personality', but also remember that the ASEAN Declaration (AD) in 1967 and the TAC in SEA in 1976 have the same legal personality. So, for 45 years of its existence, ASEAN proved that it had effective and supportive institutional framework for integration tidiness with clarity of purpose. Therefore, I think it is anachronistic and an oxymoronic argument to say that ASEAN now needs a legal personality with a framework to be "formal, equipped with the explicit treatybased, legally-binding and regulations, and standing body or secretariat to monitor compliance with those rules" (Bhattacharyay, 2010: 18).

It is not necessarily formal and rigid organization that connotes a certain tidiness and clarity of purpose. For example, ASEAN initiated ASEAN + 3, ASEAN Regional Forum (ARF), East Asia Summit (EAS), ASEAN Maritime Forum (AMF), and the ASEAN Defense Ministers' Meeting Plus (ADMM-Plus) that have delivered agenda setting and peaceful engagement by ASEAN in a-consultative and deliberate ways. The concrete result of these approaches can be seen from the significance 
of ARF in security politics. It is predicated on the norms behavior based on consensus, noninterference, and non-use force. The ARF is the world's only regional gathering that includes Europe, the US, and China. Although, the ARF is centered on ASEAN, it has allowed nonASEAN states to contribute to the ASEAN's political agenda. Other significant achievement is the willingness of major powers to confirm with TAC. Acknowledging TAC means acknowledging ASEAN Way that had been built in a flexible way since its inception.

In a micro-analysis, when ASEAN leads, it gives ASEAN countries the opportunity to channel their national interests. This is because not all ASEAN countries have enough capabilities and capacities. In other words, ASEAN countries will have capacity to act based on their pivotal roles in norms production. I will discuss it more comprehensively on the next section.

This leads me to a second point and that is to wonder about how regions produce order in RA process. According to Acharya (2007: 637), IR scholars have used the concept of order in two main ways: a description of a particular status quo and in referring to increased stability and predictability. I think

4 According to A.F.K Organski, international systems are frequently dominated by a single powerful state that uses its strength to create a set of political and economic structures and norms of behaviour that enhances both the security of the leading state and the stability of the system as a whole

5 I think this is the order that Asia's RA wants to build, this is a new way of management conflict in Asia, and Asia is not alone. For example, in the Community of Latin America and Caribbean States (CELAC), 33 sovereign states of Latin America and the Caribbean region took their stance deciding what their real interests were and left behind 188 years of Monroe Doctrine in December 2011. this is not enough. The concept of order can also explain how the challenge of power distribution and results of it create power transition between dominant state and dissatisfied challengers (A.F.K Organski \& Tammen, 2000; Kugler \& Lemke, 2000). 4

ASEAN with the EA can move towards regional identity in an open regionalism that is open for any ideas, interests, and philosophical point of views, but should be exclusive in representing independent stance and voice of Asia. There is no question about who wins and who loses in bargaining because it is a mutualistic symbiotic relationship. 5

This is breakthrough in the process of RA building whereas the process of regionalism can be exclusive in a sense that it promotes cooperation and independent regional voice. As for the case in Asia, it is rooted on the bitter experience of Asia in colonization by Western powers, by proxywars, and because of intervention and subversive action from domestic and foreign actors. The latest is the calamity of 1997 Asian financial crisis done by agents of globalization in producing globalism and global governance

According to Huge Chavez, Monroe Doctrine is the original confirmation of US interference in the region and he openly called for CELAC to replace the OAS. Monroe doctrine was originally promulgated by the US President James Monroe in 1823 as a warning to European powers that any expansionist activity by them anywhere in the Americas would be construed as a threat to the US. See Juan Gabriel Tokatlian. (2009) The end of Monroe doctrine. The Santiago Times [Online], January, p. 5. Available from: <http://www.santiagotimes.cl/thesantiago-times/category/14-january-

2009?download=404:23-jan-09> [Accessed 26 September 2012]. 
in international liberalism. ${ }^{6}$

The unparalleled and omnipresence of the US as a de facto resident superpower in Asia has made it slightly difficult for Asia to mold a neutral regional identity in the global community. Lacking cooperation in this fluid, sensitive, and tough environment, the EA states are looking at ASEAN as a mediator to ease the tension between them in the EA's complex power structure. The EA states think that ASEAN is an innovative, flexible, and friendly regional block. This is because the ASEAN states embrace policy of noninterference, respect for sovereignty, and nonviolent stance to resolve dispute between them as stated in the ASEAN charter (AC).

The main characteristic of ASEAN is openness based on a mutualistic symbiotic relationship that does not intend to make any military/defense alliances or a common foreign policy. ASEAN never developed collective approaches in security arrangements, those have always been bilateral. The SEA region is then open to any non-hostile country that wants to cooperate

\footnotetext{
${ }^{6}$ The sovereign state's capacity for independent political action is weakened by globalization, especially in the area of economic policy. According to critical theorists, such as Cox, Rosenberg, and Cutler, the emergence of globalization is actually the development of a new form of imperial power, and hegemony, in which the growing influence of private actors has blurred the boundaries between private and public authority in the global realm. Therefore, I think this is why ASEAN constructs its role in Asia's RA that prevents erosion to national sovereignty by the process of globalization and global governance because mostly Asians got their independence from a bitter struggle against Western colonialism. ASEAN is likely to think that the RA process should be autonomous and multi-polar, and should preserve local wisdom and traditions. See Amien Rais. (2008) Agenda mendesak bangsa. Selamatkan Indonesia! (Urgent agenda of the nation: save Indonesia!). Yogyakarta: PPSK Press, pp. 11-18, 81-94;
}

with it peacefully (Kamasa, 2010). This is why the centrality of ASEAN is important to play its role in the process of architecture building in the region.

With its centrality, ASEAN can play a role as a confidence builder, bridge builder, peace maker, and problem solver to enhance peace and stability in the region. ASEAN should come together as the united stand in an RA process in order to reach common ground in solving regional and world problem. In this 'turbulent age', it is easy to get stuck on dichotomies or on a kind of slippery slope. But, to be able to see the world through the thoughts of different cultures and viewpoints completely different from ours, it is a truly beautiful accomplishment and decisions are valued only when they are met freely.

This is what ASEAN were striving because when it is done under pressure by a power, it is naturally undemocratic. When it is undemocratic, it cannot be accepted so easily. The credibility of such decisions gets lost and the credibility of such organization is reduced. ${ }^{7}$ With this role, I think ASEAN can be solid

Jeffrey Frieden. (2006) Global capitalism: its fall and rise in the twentieth century. New York: W.W. Norton \& Company, pp. 469-471; Martin Griffiths, Terry O'Callaghan, \& Steven Roach (2008) International relations: the key concepts. New York: Routledge, p. 132; Steven Roach ed. (2007) Critical theory and international relations: a reader. London: Routledge, pp. 267-283.

7 As can be seen from mounting US pressure on the SEA nations to isolate Myanmar or when SCS issue has put them the tough spot of having to choose between backing a neighbour and risking relations with the US. See BBC. (2012) Clinton urges ASEAN unity over South China Sea rows [Online], BBC News. Available from: <http://www.bbc.co.uk/news/world-asia-19435346>

[Accessed 5 September 2012]; Takatoshi Ito. (1993) U.S. Political Pressure and Economic Liberalization in East Asia. The National Bureau of Economic Research [Online], January. Available from: 
internally and become a responsible global community.

Third, if we have norms and order, then we can reconcile economic-security nexus. What is important for ASEAN in contemporary Asia's RA is to not perceive itself as having the stark choices of either economic or security nexus. Both are important because if the region does not have a political stability, then it would be difficult to achieve economic prosperity and vice versa.

The nature of Asia is to look for a harmonious path in every way and resolve the disputes in a peaceful manner. In the contemporary of IR literature, it can be interpreted that ASEAN is looking for balancing and not to bandwagon with powerful actors (Rachmianto, 2011; Tow \& Acharya, 2007; Goh, 2005). Indonesia has called this phenomenon as balance and dynamic equilibrium (Natalegawa, 2010 \& 2011) Pattiradjawane, 2012, Hitipeuw, 2012). The critical reading of this policy explains that it needs wider flexibility in decision-making processes, assertiveness, and certainty so that no enemies are made and a million friends are made in economic and security cooperation (Mardhatillah, 2011).

If economic and security are inextricably linked, then how do we distinguish it as a policy priority? I think it is important that we recognize five key questions to answer this. For security issues: what counts as an issue? Who are we trying to secure? Who or what are we trying to secure against? How is security achieved? How is security reviewed? For economic issues: what counts as an issue? What should be produced? How should goods and services be produced? For whom should goods and services be produced? How are economic benefits achieved? Answering these questions is not easy and we will need careful

<http://www.nber.org/chapters/c7843.pdf> [Accessed 1 October 2012]; New Straits Times. (1997) Myanmar likely to be ASEAN member despite US pressure, New Straits Times. Available from: $<$ http://news.google.com/newspapers?nid=1309\&dat=1 9970427\&id $=$ X7BOAAAAIBAJ\&sjid=GBUEAAAAIBAJ\& $\mathrm{pg}=3739,5748762 \% 29>$ [Accessed 27 September 2012]; examination and investigation on how to choose system, regimes, and the value of the best alternative among the alternatives available.

In regards to this, I would argue that ASEAN can reconcile its security and economic nexus in an ideal and pragmatic way. There are no such absolutes in this analytical point of view simply because there are no such common norms and values that exist in ASEAN other than governing relations between them as a state which are contained in the $\mathrm{AD}$ of 1967 and TAC of 1976, and are elaborated further in the AC in November 2007. These are "(1) mutual respect for independence, sovereignty, equality, territorial integrity, and national identity of all nations; (2) the right of every state to lead its national existence free from external interference, subversion or coercion; (3) non-interference in the internal affairs of one another; (4) settlement of differences or dispute by peaceful manner; (5) renunciation of threat or use of force; and (6) effective cooperation among themselves" (ASEAN, 2005: 6-7).

There are no short-cuts and instant results. Everything must be a process and any hasty, reckless, and careless actions by intervening in process of diplomacy will be doomed to fail. With the inception of $\mathrm{AC}$ it does not mean that ASEAN cannot play the role of ambiguity and perseverance to achieve desired outcomes. Ambiguity is not necessarily bad, in fact in the case of ASEAN, it enhances cooperation. For example, Indonesia and Vietnam conducted negotiations for almost 25 years regarding maritime boundaries before they were completed (Arsana, 2011). This proves that with slight improvements and modifications, ASEAN nations can strive together to the attainment of prosperous, secure, and harmonious SEA. It is by no means

Xinhua. (2012) China says US strategic pressure not conducive to Asia's development, US interests, Xinhua. Available from: <http://www.namnewsnetwork.org/v3/read.php?id=MjA wMTg5> [Accessed 27 September 2012] 
easy. Even before the AC was signed, for 40 years, ASEAN "[had] intervened in some domestic situations that were perceived to be affecting the other member countries and the association itself" (Severino, 2006: 94-96).

In regard to the $\mathrm{AC}$, I think ASEAN will not likely be consolidated into a homogenous grouping in a common economic, security, financial, monetary, and foreign policy. A 'coherent concept of ambiguity' is a commonly held vision by ASEAN used to control the dynamics in the region and to protect national sovereignty in the sclerosis of RA process. It is likely that ASEAN is not interested to attach itself to stronger regional or global building blocks as this will make it a subordinate. I do not think this will be in the minds of independent ASEAN states.

In order for RA in Asia to work, I think what more likely to happen is to ask how to enhance and nourish the region with a good feeling and enhanced trust. This is important in order to diminish distrust and foster mutual symbiotic cooperation in a conducive environment.

\section{Challenges and Opportunities}

The world is constantly changing and the only constant is change. This happening is also the case in IR. In contemporary IR, the world dimensions create at least four global challenges which are the challenge of interdependence, the challenge of nuclear danger, the challenge of environment crisis, and the challenge of society's moral decline. For sure, ASEAN has to deal with all these challenges. But, to be specific, there are three challenges that ASEAN have: power interplay, the ASEAN way sustainability, cynical view that ASEAN is a self-absorbed organization. With these, come also three opportunities: fostering peaceful strategic environment, cultivating the progress of ASEAN-initiated matters with its external partners, and promoting specific issue.

ASEAN does not want to enforce cooperation among its members; instead it has to be self-consciousness of compliance. ASEAN does so in at least four ways: by setting standards of behavior, deliberating compliance, reducing the costs of joint decision making, and resolving disputes. I will explore how exactly the mechanism in ASEAN to tackle challenges and to seize opportunities lies ahead in order to shape RA in Asia.

The first challenge is about power interplay inside ASEAN where each country has its national interests, different norms, and expectations. This has potential to reduce the capacity of ASEAN centrality to act on behalf of its member states if it does not deal carefully and wisely enough. However it can be tackled by cultivating trust in a friendly dialogue, incorporating as many mechanisms as possible to advance ASEAN principles, enhancing transparency, and building confidence. ASEAN should keep their status as a modest regional building block that has a strong cooperative tradition in an inclusive but limited, informal but serious, and ambitious but gradual steps (Sukma, 2014: 1-5).

Any formalization with legal consequence and intervention in a state sovereignty is contra-productive for regional dynamics and sustainability. ASEAN's power interplay should consider level of ability of its member in a process of interaction and integration. Therefore, RA process driven by the ASEAN way should pay attention to the effect on environment and culture, on political systems, and on economic development, prosperity, and human physical wellbeing locally and globally. It is about wisdom and sensitivity to weigh the good and the bad aspects of RA process for ASEAN and foe the region as a whole.

With the first challenge, comes also the first opportunity. ASEAN has been successful in fostering a relatively peaceful strategic environment and prosperous region in SEA. This is because SEA has proved to be a peaceful region before Western imperialism and the proxy-wars after decolonization (Mishra, 2012; Lockard, 2009; Sardesai, 2003)

After the establishment of ASEAN there has been strong and harmonious relationship among SEA nations even though it is true that there is skirmish between Vietnam and Cambodia and there are still minor territorial disputes. ASEAN has been built based on overlapping norms, shared values, and capacity of each country. It gives ASEAN a relatively good cohesiveness stock which in turn provides a driving force for ASEAN as a 
norms producer. This spirit of sharing and caring were fostered in independent ways.

By virtue of the differences among them in geographical location, historical experience, and cultural outlook, ASEAN nations, of course, differ in their assessment of the US and China role in their national life. They have their own preferences and calculations in their evaluation of the costs, benefits, and potential gain to be achieved from that. However, the ASEAN nations share certain basic understandings with respect to the US and China. One of their main understandings is to allow the US and China to compete effectively in the region and to influence the RA process as long as they do not breach the very principles of ASEAN. ${ }^{8}$

In other words, ASEAN will welcome security under the US umbrella and prosperity under Chinese liquidity or vice versa. However, there are some concerns on this policy. One of their main concerns is on how to prevent any aspiration of hegemony in the region imposed by military force. The ASEAN members acknowledge the importance of the US and China role in the global and regional affairs. In the light of the South China Sea (SCS) row for example, ASEAN nations pursued CBM9 to engage with China for the sake of peace and stability in the region and to gradually try

8 This is what ASEAN called as cross cultural understanding to enhance of mutual respect for independence, sovereignty, equality, territorial integrity, and national identity. See in ASEAN. (2011) Declaration of the $6^{\text {th }}$ East Asia summit on ASEAN connecivity. The ASEAN Secretariat [Online], November. Available from: <http://www.aseansec.org/documents/19th\%20summit/ EAS\%20Connectivity.pdf> [Accessed 3 October 2012]; ASEAN. (2011) Declaration of the East Asia summit on the principles for mutual beneficial relations. The ASEAN Secretariat [Online], November. Available from: <http://www.aseansec.org/documents/19th\%20summit/ EAS\%20Principles.pdf > [Accessed 3 October 2012].

$9 \mathrm{~A} \mathrm{CBM}$ is an action that reflects goodwill or willingness to exchange information with an adversary. The purpose of such is to decrease misunderstanding, tension, far, anxiety, and conflict between two or more parties by settling the jurisdictional disputes (Severino, 2006: 180-189).

The second challenge is about sustaining the ASEAN way. What is the ASEAN way exactly? It is a framework of norms to enhance regional prosperity and security. The ASEAN way is founded on the key norm of responsible global community such as territorial integrity and sovereign equality. In my view, it is a norm based on a shared cultural perspective that emphasizes the importance of Asian forms of knowledge, consensus-based decision making, gradualism and the balance of politics and economics over institutions from diverse philosophical point of views. The central norms that constitute the ASEAN way are non-interference in the domestic affairs of other states, a consensus-based style of decision-making, and the non-use of force to settle dispute. ${ }^{10}$

This second challenge has been on how to raise an opportunity to cultivate the progress of ASEAN-initiated matters with its external partners within the regional process framework of ASEAN +1, ASEAN+3, ARF, and EAS while maintaining ASEAN centrality. The norm of non-interference provides a justification for the establishment and global recognition of the region. This recognition contributed to the external legitimization of the

emphasizing trust and limiting conflict escalation as a form of preventive diplomacy. See Sophie Harman. (2007). Confidence building measeure, in: Encyclopedia of Governance. California: Sage Reference, pp. 137-138.

${ }^{10}$ The "ASEAN way" as an open regional cooperation and respect for sovereignty has worked constructively in balancing RA process to produce independent order that correlates with global stability. See also what Michael Haas, Alex Bellamy and Amitav Acharya explained about it in William Tow ed. (2009) Security politics in the Asia Pasific: a regional global nexus?. Cambridge: Cambridge University Press, pp. 12-15, 169; Amitav Acharya. (2007)

The emerging regional architecture of world politics. (New Jersey: Princeton University), pp. 629-652; Yukiko Nishikawa. (2007) The "ASEAN Way" and Asian Regional Security. The "ASEAN way" ad Asian regional security. (New York: Blackwell Publishing), pp. 44-50. 
region's states and regimes because it contributed to establish an image of independence and made it more difficult for outside powers to interfere in the region's states, whilst leaving open the possibility that SEA states might conduct bilateral relationship.

Last but not least is the challenge relating to the cynical view that ASEAN is selfabsorbed and does not actually deliver concrete results. ASEAN might move towards an EA wide community and the puzzle is how ASEAN can live up to this notion of ASEAN centrality. It has to be earned by really ensuring that there is no gap between ASEAN supposed regional aspirations and the reality of bilateral relationship and that there are no acute complications in their relationship. If there is, such as the SCS row, there should be an initiative in offering its good offices to resolve the dispute. This is done, for example, by Indonesia's shuttle diplomacy to bridge that tension.

The RA building in Asia is not a new concept for ASEAN because in 2003, ASEAN has invested in building ASEAN Community. Furthermore, ASEAN now have ASEAN +1, ASEAN + 3 , ARF, and EAS. This is a multi-tack path that provides many ways for delivering common interests in different perspectives or strategies. It also represents or acknowledges that the region is so fluid, so dynamic, and it is in a constant state of change. But what is not to change is this process of deepening cooperation, greater interaction, and greater integration in an equal, fair, flexible, and peaceful way. ${ }^{11}$

This last challenge has raised an opportunity regarding the specific issue of human rights achievement. I argue that the promotion of human rights is in progress under the political development thrust of the ASEAN Security Community. ASEAN has

${ }_{11}$ I argue this trend can be called as a mini-lateral group where the SEA, the EA, and the Asia-Pacific countries cooperate with each other. It has the rationale and specific scope of cooperation; recognizing China's role and the US' stance. More crucial, it is put importance on ASEAN central role in steering RA process. I think ASEAN will thereby assumed the obligation to promote awareness on human rights and to take necessary measures leading to establishment of a human rights mechanism. I argue this kind of human rights inception should be neutral and cannot be used as a tool of intervention in the name of humanitarian action such that happened in East Timor or more recently in Libya (Allen 2012, O’Connor, 2009, Kingsbury, 2007).

\section{Conclusion}

To conclude, ASEAN's role in contemporary Asian RA is crucial and important. ASEAN has a role as a trusted broker and careful driving force. ASEAN acted in a solid enough way to project Asia identity. It leads by giving example. It has objectives to keep the balance in the region by keeping the RA process broad, loose, and multilayered. ASEAN has seized the opportunities of regional dynamics in a constructive and nonintervention manner. It is a slow process but the results are substantial in keeping the region prosperous and stable. ASEAN will not likely be consolidated into a homogenous grouping in a common economic, security, financial, monetary, and foreign policy. In order for RA in Asia to work, what more likely to happen is to ask how to enhance and nourish the region with a good feeling and enhanced trust. This is important in order to diminish distrust and foster mutualistic symbiotic cooperation in a conducive environment. There are three challenges that ASEAN have: power interplay, the ASEAN way sustainability, and cynical view that ASEAN is a self-absorbed organization. With these, come also three opportunities: fostering peaceful strategic environment, cultivating the progress of ASEAN-initiated matters with its external partners, and promoting specific issue. ASEAN exploits these opportunities and tackles the challenges of the fluid strategic environment in the region by

likely stick to this path by not taking side, but to reconcile any disputed parties in order to maintain region's stability and security. It is important for ASEAN to nurture multipolar initiatives and polycentric world, to provide solutions to the new economic-security challenges, and to ensure that ASEAN does not lose its independence. 
playing an active role in external relations, nourishing trust, building confidence in the region, and keeping the internal solidity between the members in the midst of different national interests. These are the key success of ASEAN to project Asian identity and RA.

\section{Bibliography}

\section{Books and Articles}

Acharya, A. (1993) A new regional order in South-East Asia: ASEAN in the postcold war era, adelphi paper 279. Oxford: Oxford University Press/IISS. . (2007) The emerging regional architcture of world politics. (Kota: Penerbit).

ASEAN. (2008) The ASEAN charter. Jakarta: The ASEAN Secretariat.

Ball, D. (1999) The evolving security architecture in the Asia-Pacific region. Canberra: Australian National University.

Besson, M. (2004) Contemporary Southeast Asia: regional dynamics, national differences. New York: Palgrave Macmillan.

Bhattacharyay, B. N. (2010) Institutions for Asian connectivity. Journal of International Commerce, Economics and Policy (JICEP), pp. 309-335.

Bisley, N. (2007) East Asia's changing regional architecture: towards an East Asian economic community?. (Pacific Affairs).

Budiman, A. (2008) Masyarakat ekonomi ASEAN 2015: memperkuat sinergi ASEAN di tengah kompetensi global (ASEAN economic community 2015: strengthening ASEAN synergy in the middle of global competition). Jakarta: Elex Media Komputindo.

Buzan, B. \& Wæver, O. (2003) Regions and owers: the structure of international security. Cambridge: Cambridge University Press.

Chalmers, M. (1997) ASEAN and confidence building: continuity and change after the Cold War. Contemporary Security Policy 18 (3), p. 53.

Darity, W. (2008) Postnationalism, in:
International Encyclopedia of the Social Sciences. Detroit: Macmillan Reference.

East Asia Vision Group (2002) final report of the East Asia study group. Phnom Penh: ASEAN.

Frieden, J. (2006) Global capitalism: its fall and rise in the twentieth century. New York: W.W. Norton \& Company.

Friedrichs, J. (2012) East Asian regional security: what the ASEAN family can (not) do. (Kota: Penerbit).

Goh, E. (2005) Meeting the China challange: the U.S. in Southeast Asian regional security strategies. Washington: EastWest Center.

Griffiths, M., O'Callaghan, T., \& Roach, S. (2008) International relations: the key concepts. New York: Routledge.

Hall, M., \& Jackson, P. T. (2007) Civilizational identity. the production and reproduction of "civilizations" in international relations. New York: Palgrave Macmillan.

Harman, S. (2007) Confidence building measure, in: Encyclopedia of Governance. California: Sage Reference.

Hitt, M., \& R. Duane, I. (2005) Achieving and maintaining strategic competitiveness in the 21st century: the role of strategic leadership. (Academy of Management Executive).

Kapuchu, N. (2007) Strategic planning, in: Encylopedia of Governance. California: Sage Reference.

Kemlu (2010) Prospek perkembangan strategis arsitektur kawasan Asia Pasifik 2010-2020: implikasinya bagi politik luar negeri RI (prospect of regional architecture strategic development in Asia-Pacific 20102020: implication for the Indonesian foreign policy). Jakarta: BPPK.

Kingsbury, D. (2007) Timor-Leste: the harsh reality after independence. (Singapore: Institute of Southeast Asian Studies).

Lockard, C. (2009) Southeast Asia in world history. Oxford: Oxford University Press.

Midlarsky, M. (2000) The power transition 
research program: assessing theoretical and empirical advances. In Lemke, D. \& Kugler, J. The handbook of war studies II. Michigan: University of Michigan Press, pp. 129-163.

Nishikawa, Y. (2007) The "ASEAN way" and Asian regional security. (New York: Blackwell Publishing).

Organski, A., \& Tammen, R. (2000) Power transitions: strategies for the $21^{\text {st }}$ century. New York: Chatham House.

Rais, A. (2008) Agenda mendesak bangsa. Selamatkan Indonesia! (Urgent agenda of the nation: Save indonesia!). Yogyakarta: PPSK Press.

Rachmianto, A. (2011) Building new regional architecture in East asia: the role of ASEAN. Jurnal Diplomasi, pp. 67-85.

Rasyid, A. A. (2008) Bangkitnya perekonomian Asia Timur: satu dekade setelah krisis (The rise of East Asia's economy: decade after crisis). Jakarta: Elex Media Komputindo.

Reyes, V., Shie, T. R., \& Lizaso, M. (2004) Transformations: a region in the making. Manila: Far Eastern University.

Roach, S. (2007) Critical theory and international relations. London: Routledge.

Ruggie, J. G. (2003) Constructing the world polity: essays on international institutionalization. London: Routledge.

Sardesai, D. (2003) Southeast Asia: past and present. New York: Westview Press.

Severino, R. (2006) Southeast Asia in search of an ASEAN community:insights from the former ASEAN secretarygeneral. Singapore: ISEAS Publishing.

Stryker, S. (2001). Identity theory, in: Encyclopedia of Sociology. New York: Macmillan.

Sukma, R. (2014) ASEAN beyond 2015: the imperative for further institutional changes. Jakarta: Centre for Strategic and International Studies.

Tow, W. (2009) Security politics in the AsiaPacific: a regional global nexus?. Cambridge: Cambridge University Press.

Tow, W. \& Taylor, B. (January 2010) What is
Asian security architecture?. Review of International Studies, pp. 95-116.

$\mathrm{Xu}, \mathrm{M}$. (2007) Awareness and assessment of strategic intelligence: a diagnostic tool. In Xu, M. Managing strategic intelligence: techniques and technologies. Philadelphia: Information Science Reference, pp. 122-140.

\section{Electronic Media}

Allen, P. (2012) Gaddafi was killed by French secret serviceman on orders of Nicolas Sarkozy, sources claim [Online], Mail Online. Available from: <http://www.dailymail.co.uk/news/a rticle-2210759/Gaddafi-killedFrench-secret-serviceman-ordersNicolas-Sarkozy-sourcesclaim.html?ito=feeds-newsxml> [Accessed 30 September 2012].

Arsana, M. A. (2011) Predicting Indonesia's maritime boundaries [Online], The Jakarta Post. Available from: <http://www.thejakartapost.com/ne ws/2011/12/22/predicting-indonesias-maritime-boundaries.html>

[Accessed 22 September 2012].

ASEAN. (2005) Text of the treaty of amity and cooperation in Southeast Asia. ASEAN [Online], March. Available from: $<$ http://www.aseansec.org/TACKnowledgeKit.pdf> [Accessed 6 August 2012].

. (2011) Declaration of the $6^{\text {th }}$ East Asia summit on ASEAN connectivity. The ASEAN Secretariat [Online], November. Available from: <http://www.aseansec.org/document s/19th\%2osummit/EAS\%2oConnecti vity.pdf $>$ [Accessed 3 October 2012].

. (2011) Declaration of the East Asia summit on the principles for mutual beneficial relations. The ASEAN Secretariat [Online], November. Available from: <http://www.aseansec.org/document s/19th\%20summit/EAS\%20Principle s.pdf $>$ [Accessed 3 October 2012].

. (2012) ASEAN community in figures 
2011. The ASEAN Secretariat [Online], April. Available from: $<$ http://www.aseansec.org/document s/ASEAN\%20community\%2oin\%2ofi gures.pdf $>$ [Accessed 7 August 2012].

BBC. (2012) Clinton urges ASEAN unity over South China Sea rows [Online], BBC. Available from: <http://www.bbc.co.uk/news/worldasia-19435346> [Accessed 5 September 2012].

Bergmann, A. (2011) World's largest economies [Online], CNN Money. Available from: <http://money.cnn.com/news/econo my/world_economies_gdp/> [Accessed 1 October 2012].

Clinton, H. R. (2010) Remarks on regional architecture in Asia: principles and priorities [Online], U.S. Department of State. Available from: <http://www.state.gov/secretary/rm/ 2010/01/135090.htm > [Accessed 1 October 2012].

Donghyun, P. \& Estrada, G. (2009) Are developing Asia's foreign exchange reserves excessive? An empirical examination [Online], ADB Economic Working Paper Series. Available from: $<$ www.afdc.org.cn/afdc/down_resear ch.asp?id=32> [Accessed 25 September 2012].

Dormandy, X. (2012) Prepared for future threats? US defense partnerships in the Asia-Pacific region. Chatham House [Online], June. Available from: <http://www.chathamhouse.org/sites /default/files/public/Research/Ameri cas/pro612dormandy.pdf> [Accessed 16 September 2012].

East Asia Vision Group. (2001) Towards an East Asia community: regions of peace, prosperity, and progress. Ministry of Foreign Affairs of Japan [Online]. Available from: <http://www.mofa.go.jp/\%5Cregion/ asia-paci/report2001.pdf $>$ [Accessed 26 September 2012].

. (2005) ASEAN +3 document series 1999-2004. The ASEAN Secretariat [Online], April. Available from: <http://www.aseansec.org/ASEAN+3 .pdf $>$ [Accessed 6 October 2012].

European Union. (2011) Main traders in the world. European Union Trade Committee [Online]. Available from: $<$ www.trade.ec.europa.eu/doclib/doc s/2006/september/tradoc_122529.pd $\mathrm{f}>$ [Accessed 20 September 2012].

Fenenko, A. (2012) Russian foreign policy: Focusing on Asia [Online], Valdai Discussion Club. Available from: <http://valdaiclub.com/politics/3990 o.html $>$ [Accessed 26 July 2012].

Hitipeuw, J. (2012) SBY: Indonesia to improve its role in int'l cooperation [Online], Kompas. Available from: <http://english.kompas.com/read/20 12/02/15/15494911/SBY.Indonesia.to .Improve.Its.Role.in.Intl.Cooperation $>$ [Accessed 10 September 2012].

Human Security Project. (2011) Human security report 2009/2010: the causes of peace and the shrinking costs of war [Online], Human Security Report. Available from: http://www.hsrgroup.org/humansecurityreports/20092010/overview.aspx [Accessed 26 July 2012].

Ito, T. (1993) U.S. political pressure and the economic liberalization in East Asia. The National Bureau of Economic Research [Online], January. Available from:

$<$ http://www.nber.org/chapters/c784 3.pdf $>$ [Accessed 1 October 2012].

Jiechi, Y. (2007) Address by Chinese foreign minister Yang Jiechi at ASAN plus three foreign ministers meeting [Online], Ministry of Foreign Affairs of the People's Republic of China. Available from: <http://www.fmprc.gov.cn/eng/wjdt/ zyjh/t346540.htm> [Accessed 5 October 2012].

Kamasa, F. (2010) Future of ASEAN and ties with Korea [Online], The Korea Times. Available from: <http://www.koreatimes.co.kr/www/ news/include/print.asp?newsIdx $=697$ 36> [Accessed 1 October 2012].

Leung, S. (2012) China to overtake U.S. as largest trading nation, HSBC says 
[Online], --Bloomberg. Available from: <http://www.bloomberg.com/news/2 012-02-21/china-to-overtake-u-s-aslargest-trading-nation-hsbcsays.html> [Accessed 21 September 2012].

Medvedev, D. (2010) Speech at the second ASEAN-Russia summit [Online], President of Russia. Available from: $<$ http://eng.kremlin.ru/transcripts/1 226> [Accessed 10 October 2012].

Meriam-Webster. (2012) Strategic [Online], Encyclopaedia Britannica Company. Available from: <http://www.merriamwebster.com/dictionary/strategic > [Accessed 2012].

Mishra, P. (2012) The ruins of empire: Asia's emergence from western imperialism [Online], The Guardian. Available fom:

<http://www.guardian.co.uk/books/2 012/jul/27/ruins-of-empire-pankajmishra> [Accessed 27 September 2012].

Morrison, W. \& Labonte, M. (2011) China's holdings of U.S. securities: Implications for the U.S. economy. Congressional Research Service [Online]. Available from: <http://www.fas.org/sgp/crs/row/RL 34314.pdf $>$ [Accessed 1 October 2012].

Nanto, D. (2008) East Asian regional architecture: new economic and security arrangements and U.S. policy. Congressional Research Service [Online], January. Available from: <http://www.fas.org/sgp/crs/row/RL 33653.pdf> [Accessed 16 September 2012].

Natalegawa, M. (2010) Speech by H.E. Dr. R.M. Marty M. Natalegawa minister for foreign affairs of the Republic of Indonesia at the flag hosting in commemorating ASEAN's $43^{\text {rd }}$ anniversary [Online], Kementerian Luar Negeri Republik Indonesia. Available from: <http://www.deplu.go.id/Lists/Speec hesAndTranscription/DispForm.aspx ?ID=671> [Accessed 10 August 2012]. . (2011) Welcoming remarks by H.E.
Dr. R.M. Marty M. Natalegawa minister for foreign affairs Republic of Indonesia at the $44^{\text {th }}$ ASEAN foreign ministers' meeting, Bali, Indonesia, 19 July 2011 [Online], Kementerian Luar Negeri Republik Indonesia. Available from:

<http://www.deplu.go.id/Pages/Spee chTranscriptionDisplay.aspx?Name1= Pidato $\&$ Name $2=$ Menteri\&IDP $=721 \& \mathrm{l}$ $=$ en $>$ [Accessed 19 August 2012].

National Defense University. (2012) The air university [Online], Strategic Leadership and Decision Making. Available from: <http://www.au.af.mil/au/awc/awcg ate/ndu/strat-ldr-dm/pt1ch2.html > [Accessed 28 September 2012].

Nehru, V. (2011) Southeast Asia: Crouching tiger or hidden dragon? [Online], Carnegie Endowment for International Peace. Available from: $<$ http://carnegieendowment.org/ieb/ 2011/07/07/southeast-asiacrouching-tiger-or-hiddendragon/2wc7> [Accessed 26 July 2012].

O'Connor, P. (2009) Australian imperialism, the 1999 East Timor intervention and the pseudo-left [Online], World Socialist Web Site. Available from: <http://www.wsws.org/articles/2009 /nov2009/etim-n02.shtml> [Accessed 6 October 2012].

Pattiradjawane, R. (2012) Kombinasi dinamis dalam keseimbangan baru (Dynamic combination in a new dynamic equilibrium) [Online], Kompas. Available from: <http://kesehatan.kompas.com/read /2012/02/11/03420992/Kombinasi.D inamis.dalam.Keseimbangan.Baru > [Accessed 11 October 2012].

Reuters. (1997) Myanmar likely to be ASEAN members despite US pressure [Online], New Straits Times. Available from:

<http://news.google.com/newspapers ?nid $=1309 \&$ dat $=19970427 \&$ id $=$ X7BO AAAAIBAJ\&sjid=GBUEAAAAIBAJ\&p $\mathrm{g}=3739,5748762 \% 29>\quad$ [Accessed 27 September 2012]. 
The Economist. (2010) Dating game. when will China overtake America? [Online], . The Economist. Available from: $<$ http://www.economist.com/node/1 7733177> [Accessed 1 October 2012].

The World Bank. (2011) World development indicators [Online]. Available from: The World Bank http://siteresources.worldbank.org/D ATASTATISTICS/Resources/wdi_ebo ok.pdf [Accessed 7 September 2012].

Tokatlian, J. G. (2009) The end of Monroe doctrine [Online], The Santiago Times. Available from: $<$ www.santiagotimes.cl/the-santiagotimes/category/14-january2009?download=404:23-jan-09> [Accessed 26 September 2012].

Tow, W. \& Acharya, A. (2007) Obstinate or obsolete? The US alliance structure in the Asia-Pacific. ANU [Online]. Available from: $<$ http://ips.cap.anu.edu.au/ir/pubs/ work_papers/o7-4.pdf > [Accessed 10 October 2012].

Umar, A. R. (2011) A critical reading of 'Natalegawa doctrine' [Online], The Jakarta Post. Available from: <http://www.thejakartapost.com/ne ws/2011/01/o7/a-critical-reading\%E2\%80\%98natalegawadoctrine\%E2\%80\%99.html> [Accessed 10 August 2012].

World Nuclear Association. (2013) Asia's nuclear energy growth [Online], World Nuclear Association. Available from: $<$ http://www.worldnuclear.org/info/countryprofiles/others/asia-s-nuclear-energygrowth/> [Accessed 2 June 2014].

Xinhua. (2012) China says US strategic pressure not conducive to Asia's development [Online], NAM News Network. Available from: $<$ http://www.namnewsnetwork.org/v 3/read.php?id=MjAwMTg5 >

[Accessed 1 September 2012]. 